\title{
Thermoanaerobacter pseudethanolicus sp. nov., a thermophilic heterotrophic anaerobe from Yellowstone National Park
}

Correspondence Juergen Wiegel jwiegel@uga.edu

\author{
Rob U. Onyenwoke, ${ }^{1}$ Vadim V. Kevbrin, ${ }^{2}$ Anatolly. M. Lysenko ${ }^{2}$ \\ and Juergen Wiegel ${ }^{1}$
}

\author{
${ }^{1}$ Department of Microbiology, The University of Georgia, Athens, GA 30602-2605, USA \\ ${ }^{2}$ Winogradsky Institute of Microbiology, Russian Academy of Sciences, Prospect 60-letiya \\ Oktyabrya 7/2, 117312 Moscow, Russia
}

\begin{abstract}
Strain $39 \mathrm{E}^{\top}$, originally characterized as Clostridium thermohydrosulfuricum strain $39 \mathrm{E}$ and later renamed as Thermoanaerobacter ethanolicus strain 39E, shows less than 97\% 16S rRNA gene sequence similarity with the type strain of the type species of the genus Thermoanaerobacter, T. ethanolicus strain JW $200^{\top}$. On the basis of a polyphasic analysis that included DNA-DNA hybridization studies with the subspecies of Thermoanaerobacter brockii, its closest phylogenetic relatives, strain $39 \mathrm{E}^{\top}$ represents a novel species of the genus Thermoanaerobacter, for which the name Thermoanaerobacter pseudethanolicus sp. nov. is proposed. The type strain is $39 \mathrm{E}^{\top}$ $\left(=\right.$ DSM $2355^{\top}=$ ATCC $\left.33223^{\top}\right)$.
\end{abstract}

Strain $39 \mathrm{E}^{\mathrm{T}}$ was isolated and characterized by Zeikus et al. (1980) as a strain of Clostridium thermohydrosulfuricum (Hollaus \& Sleytr, 1972) and was later described as a Thermoanaerobacter ethanolicus strain, 39E (Lee et al., 1993).

As first reported by Bateson et al. (1989) and Rainey et al. (1993), the 16S rRNA gene sequence data clearly places strain $39 \mathrm{E}^{\mathrm{T}}$ closer phylogenetically ( $>98 \%$ similarity) to the subspecies of Thermoanaerobacter brockii (Zeikus et al., 1979), i.e. T. brockii subsp. brockii DSM $1457^{\mathrm{T}}$ (Zeikus et al., 1979; Lee et al., 1993; Cayol et al., 1995), T. brockii subsp. finnii DSM $3389^{\mathrm{T}}$ (Schmid et al., 1986; Cayol et al., 1995) and T. brockii subsp. lactiethylicus DSM $9801^{\mathrm{T}}$ (Cayol et al., 1995), than to T. ethanolicus strain JW $200^{\mathrm{T}}$, the type strain of the type species of the genus Thermoanaerobacter (Wiegel \& Ljungdahl, 1981; Fig. 1). To clarify the relationship between strain $39 \mathrm{E}^{\mathrm{T}}$ and the subspecies of $T$. brockii, DNA-DNA hybridization experiments were carried out.

DNA-DNA hybridization experiments were performed spectrophotometrically as described by De Ley et al. (1970) and modified by Huß et al. (1983). Chromosomal DNA for DNA-DNA hybridizations was isolated according to Marmur (1961). The results of DNA-DNA hybridizations between strain $39 \mathrm{E}^{\mathrm{T}}$ and T. brockii subsp. brockii DSM

The GenBank/EMBL/DDBJ accession number for the 16S rRNA gene sequence of strain $39 E^{\top}$ is L09164.

The results of DNA-DNA hybridizations between strain $39 \mathrm{E}^{\top}$ and three Thermoanaerobacter brockii subspecies are presented in a supplementary table available with the online version of this paper.
$1457^{\mathrm{T}}$, T. brockii subsp. finnii DSM $3389^{\mathrm{T}}$ and T. brockii subsp. lactiethylicus DSM $9801^{\mathrm{T}}$ gave reassociation values of 56, 51 and $45 \%$, respectively (see Supplementary Table S1 available in IJSEM Online). The fact that all of the values were less than $70 \%$ indicates that strain $39 \mathrm{E}^{\mathrm{T}}$ is not related to any of the T. brockii subspecies at species level (Wayne et al., 1987). This result was corroborated by the Deutsche Sammlung von Mikroorganismen und Zellkulturen, Braunschweig, Germany (P. Schumann, personal communication), where a DNA-DNA reassociation value of 23-34\% was obtained (using the spectrophotometric method of De Ley et al., 1970) between strain $39 \mathrm{E}^{\mathrm{T}}$ and T. brockii subsp. brockii DSM $1457^{\mathrm{T}}$. Our DNA-DNA hybridizations between the known subspecies of T. brockii (T. brockii subsp. brockii DSM $1457^{\mathrm{T}}$ to T. brockii subsp. finnii DSM $3389^{\mathrm{T}}$ and T. brockii subsp. lactiethylicus DSM $9801^{\mathrm{T}}$ ) gave values of 65 and $67 \%$, as compared with reported values of $89-97 \%$ and $76-85 \%$, respectively. Our value for DNA-DNA hybridization between $T$. brockii subsp. finnii DSM $3389^{\mathrm{T}}$ and T. brockii subsp. lactiethylicus DSM $9801^{\mathrm{T}}$ was $62 \%$, while the reported value is $76-85 \%$. All of the values obtained in this study were significantly lower than the results obtained by Cayol et al. (1995) (see Supplementary Table S1). However, these aberrations might be due to the fact that Cayol et al. (1995) employed the tritium-labelled nucleotide method for determining DNA-DNA relatedness, whereas the results obtained in this work relied upon the spectrophotometric protocol of De Ley et al. (1970). Since our DNA-DNA hybridization results between the various $T$. brockii subspecies are not substantially below $70 \%$ (see Supplementary Table S1), no changes in the status of the subspecies T. brockii subsp. 


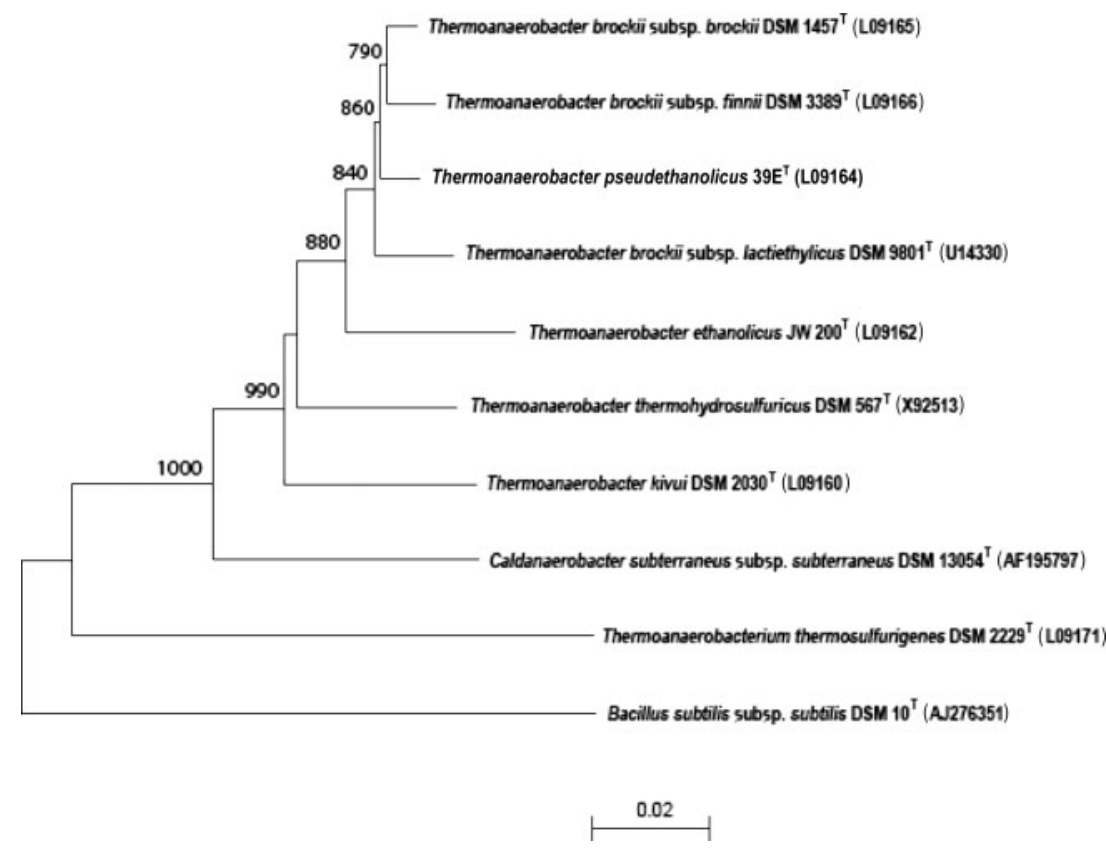

Fig. 1. Neighbour-joining phylogenetic tree, based on 16S rRNA gene sequence data with maximum-likelihood correction for synonymous changes, showing the estimated relationships between strain $39 \mathrm{E}^{\top}$ and related taxa. The $16 \mathrm{~S}$ rRNA gene sequence data used represents Escherichia coli DSM $30083^{\top}$ nucleotide positions 23-1450. Numbers at nodes indicate bootstrap percentages (based on 1000 replicates). The GenBank accession numbers for each reference strain are shown in parentheses. Bar, 0.02 nucleotide substitutions per site.

brockii DSM $1457^{\mathrm{T}}$, T. brockii subsp. finnii DSM $3389^{\mathrm{T}}$ and T. brockii subsp. lactiethylicus DSM $9801^{\mathrm{T}}$ (Cayol et al., 1995) are proposed, although the data raise some doubts as to the validity of these subspecies, especially $T$. brockii subsp. lactiethylicus (Fig. 1). However, on the basis of the fact that the DNA-DNA hybridization values obtained for strain $39 \mathrm{E}^{\mathrm{T}}$ and the T. brockii subspecies are significantly below $70 \%$, strain $39 \mathrm{E}^{\mathrm{T}}$ does not represent a novel subspecies of $T$. brockii but instead represents a novel species of the genus Thermoanaerobacter, for which the name Thermoanaerobacter pseudethanolicus sp. nov. is proposed.

The classification of strain $39 \mathrm{E}^{\mathrm{T}}$ as a novel species is mainly based on previously published physiological properties (Table 1), 16S rRNA gene sequence analysis (Fig. 1) and DNA-DNA hybridization results. The name was chosen because strain $39 \mathrm{E}^{\mathrm{T}}$ (the proposed type strain of $T$. pseudethanolicus sp. nov.) produces fermentation products in proportions similar to those of strain JW $200^{\mathrm{T}}$ (the type strain of T. ethanolicus), with high levels of ethanol being formed per mole of glucose utilized.

\section{Description of Thermoanaerobacter pseudethanolicus sp. nov.}

Thermoanaerobacter pseudethanolicus [pseud'e.tha.no'li. cus. Gr. adj. pseudes false; N.L. adj. ethanolicus a bacteriaspecific epithet; N.L. masc. adj. pseudethanolicus a false (Thermoanaerobacter) ethanolicus].

Other names include Thermoanaerobacter ethanolicus strain 39E (Lee et al., 1993) and Clostridium thermohydrosulfuricum strain 39E (Zeikus et al., 1980).

The description is based mainly on those given by Zeikus et al. (1980) and Lee et al. (1993) for strain $39 \mathrm{E}^{\mathrm{T}}$. Cells are rod-shaped and form round, terminal, mother-celldistending (drumstick-shaped) spores during growth on xylose-containing medium. Gram-stain reaction is variable, but the cell wall is Gram-type positive (Wiegel, 1981). No polymyxin B-lipopolysaccharide interaction is found (Wiegel \& Quandt, 1982). Cells are motile and reduce thiosulfate to $\mathrm{H}_{2} \mathrm{~S}$. Fermented carbohydrates include xylose, cellobiose, starch, glucose, maltose and sucrose. No growth is observed using $\mathrm{CO}_{2} / \mathrm{H}_{2}$. The temperature optimum is $65^{\circ} \mathrm{C}$. The doubling time at $65{ }^{\circ} \mathrm{C}$ is $75 \mathrm{~min}$. The DNA G+C content of the type strain is $34.4 \pm$ $0.3 \mathrm{~mol} \%\left(T_{\mathrm{m}}\right)$.

The type strain, $39 \mathrm{E}^{\mathrm{T}}\left(=\right.$ DSM $2355^{\mathrm{T}}=$ ATCC $\left.33223^{\mathrm{T}}\right)$, was isolated from the Octopus Spring algal-bacterial mat in Yellowstone National Park, WY, USA, using modified

Table 1. Differential phenotypic characteristics for some species of the genus Thermoanaerobacter

Strains: 1, T. brockii subsp. brockii DSM $1457^{\mathrm{T}}$; 2, T. brockii subsp. finnii DSM $3389^{\mathrm{T}} ; 3$, T. brockii subsp. lactiethylicus DSM $9801^{\mathrm{T}} ; 4, \mathrm{~T}$. pseudethanolicus $39 \mathrm{E}^{\mathrm{T}} ; 5$, T. ethanolicus JW $200^{\mathrm{T}}$. Data for reference strains were taken from Cayol et al. (1995). +, Positive; -, negative; $\mathrm{v}$, variable result.

\begin{tabular}{|lccccc|}
\hline Characteristic & $\mathbf{1}$ & $\mathbf{2}$ & $\mathbf{3}$ & $\mathbf{4}$ & $\mathbf{5}$ \\
\hline Sporulation & $+^{*}$ & + & + & + & $-\dagger$ \\
Motility & - & + & + & + & + \\
Gram stain & + & $\mathrm{V}$ & + & $\mathrm{V}$ & $\mathrm{V}$ \\
Optimum growth & $65-70$ & 65 & $55-60$ & 65 & 69 \\
temperature $\left({ }^{\circ} \mathrm{C}\right)$ & & & & & \\
\hline
\end{tabular}

${ }^{\star}$ Data from Cook et al. (1991).

$\dagger$ Contains the major sporulation genes (Onyenwoke et al., 2004). 
Trypticase-yeast extract-glucose medium (containing $5 \%$ xylose instead of glucose) at $65{ }^{\circ} \mathrm{C}$.

The genome sequence for strain $39 \mathrm{E}^{\mathrm{T}}$ is presently available under the name T. ethanolicus 39E at http://genome.ornl. gov/microbial/teth_39e/.

\section{References}

Bateson, M. M., Weigel, J. \& Ward, D. M. (1989). Comparative analysis of 16S ribosomal RNA sequences of thermophilic fermentative bacteria isolated from hot spring cyanobacterial mats. Syst Appl Microbiol 12, 1-7.

Cayol, J. L., Ollivier, B., Patel, B. K. C., Ravot, G., Magot, M., Ageron, E., Grimont, P. A. D. \& Garcia, J. L. (1995). Description of Thermoanaerobacter brockii subsp. lactiethylicus subsp. nov., isolated from a deep subsurface French oil well, a proposal to reclassify Thermoanaerobacter finnii as Thermoanaerobacter brockii subsp. finnii comb. nov., and an emended description of Thermoanaerobacter brockii. Int J Syst Bacteriol 45, 783-789.

Cook, G. M., Janssen, P. H. \& Morgan, H. W. (1991). Endospore formation by Thermoanaerobium brockii HTD4. Syst Appl Microbiol 14, 240-244.

De Ley, J., Cattoir, H. \& Reynaerts, A. (1970). The quantitative measurement of DNA hybridization from renaturation rates. Eur J Biochem 12, 133-142.

Hollaus, F. \& Sleytr, U. (1972). On the taxonomy and fine structure of some hyperthermophilic saccharolytic clostridia. Arch Microbiol 86, 129-146.

Huß, V. A. R., Festl, H. \& Schleifer, K. H. (1983). Studies on the spectrophotometric determination of DNA hybridization from renaturation rates. Syst Appl Microbiol 4, 184-192.

Lee, Y. E., Jain, M. K., Lee, C., Lowe, S. E. \& Zeikus, J. G. (1993). Taxonomic distinction of saccharolytic thermophilic anaerobes: description of Thermoanaerobacterium xylanolyticum gen. nov., sp. nov., and Thermoanaerobacterium saccharolyticum gen. nov., sp. nov.; reclassification of Thermoanaerobium brockii, Clostridium thermosulfurogenes, and Clostridium thermohydrosulfuricum E100-69 as Thermoanaerobacter brockii comb. nov., Thermoanaerobacterium thermosulfurigenes comb. nov., and Thermoanaerobacter thermohydrosulfuricus comb. nov., respectively; and transfer of Clostridium thermohydrosulfuricum $39 \mathrm{E}$ to Thermoanaerobacter ethanolicus. Int J Syst Bacteriol 43, 41-51.

Marmur, J. (1961). A procedure for the isolation of deoxyribonucleic acid from microorganisms. J Mol Biol 3, 208-218.

Onyenwoke, R. U., Brill, J. A., Farahi, K. \& Wiegel, J. (2004). Sporulation genes in members of the low G $+\mathrm{C}$ Gram-type positive phylogenetic branch (Firmicutes). Arch Microbiol 182, 182-192.

Rainey, F. A., Ward, N. L., Morgan, H. W., Toalster, R. \& Stackebrandt, E. (1993). Phylogenetic analysis of anaerobic thermophilic bacteria: aid for their reclassification. J Bacteriol 175, 4772-4779.

Schmid, U., Giesel, H., Schoberth, S. M. \& Sahm, H. (1986). Thermoanaerobacter finnii spec. nov., a new ethanologenic sporogenous bacterium. Syst Appl Microbiol 8, 80-85.

Wayne, L. G., Brenner, D. J., Colwell, R. R., Grimont, P. A. D., Kandler, O., Krichevsky, M. I., Moore, L. H., Moore, W. E. C., Murray, R. G. E. \& other authors (1987). International Committee on Systematic Bacteriology. Report of the ad hoc committee on reconciliation of approaches to bacterial systematics. Int J Syst Bacteriol 37, 463-464.

Wiegel, J. (1981). Distinction between the Gram reaction and the Gram type of bacteria. Int J Syst Bacteriol 31, 88.

Wiegel, J. \& Ljungdahl, L. J. (1981). Thermoanaerobacter ethanolicus gen. nov., spec. nov., a new, extreme thermophilic, anaerobic bacterium. Arch Microbiol 128, 343-348.

Wiegel, J. \& Quandt, L. (1982). Determination of the Gram type using the reaction between polymyxin $\mathrm{B}$ and lipopolysaccharides of the outer cell wall of whole bacteria. J Gen Microbiol 128, 2261-2270.

Zeikus, J. G., Hegge, P. W. \& Anderson, M. A. (1979). Thermoanaerobacter brockii gen. nov. and sp. nov., a new chemoorganotrophic, caldoactive, anaerobic bacterium. Arch Microbiol 122, $41-48$.

Zeikus, J. G., Ben-Bassat, A. \& Hegge, P. (1980). Microbiology of methanogenesis in thermal, volcanic environments. J Bacteriol 143, 432-440. 